\title{
Attitudes and Influences toward Choosing a Business Major: The Case of Information Systems
}

\author{
James P. Downey and \\ Ronnie McGaughey \\ College of Business, \\ University of Central Arkansas, \\ Conway, AR, USA
}

jdowney@uca.edu; ronmc@uca.edu

\author{
David Roach \\ Arkansas Tech University, \\ Russellville, AR, USA \\ droach@atu.edu
}

\section{Executive Summary}

Declining enrollment in MIS Departments in Colleges of Business has been the norm for many if not most universities since the dot.com bust of 2000. This has serious repercussions for the departments involved, students, and the companies that hire MIS graduates. In order to reverse this trend, an understanding of the important factors which influence students to choose a major is critical. Of crucial importance for MIS Departments is understanding the competition: the majors students choose instead of MIS. This study examines the influences of what is probably an MIS Department's greatest competitor: other majors within the College of Business. What factors and influences propel students to major in a business discipline other than MIS? Using the Theory of Reasoned Action as a framework, this study examines the similarities and differences between two groups of business majors: MIS majors and non-MIS majors. Using a survey of 413 undergraduate business majors, this study examines the influences which shape attitudes toward choice of major and a student's intention to work in his or her major field. Using structured equation modeling, the findings suggest some common influences across all majors (interest in the field, job availability, and job security), and many differences between the two groups (aptitude, social and personal image, workload of major, and influence of family, friends, other students, and professors). These similarities and differences suggest several ways to approach undecided students with the hope of gaining additional MIS majors. This also applies to students who may consider switching majors. The results of the study provide faculty with the information needed to better counsel and advise students, enhancing a fit between student and career, while simultaneously increasing technology majors.

Keywords: Choice of major, Information technology, IT careers, Management Information Systems (MIS), Business majors, Careers, Structural Equation Modeling.

Material published as part of this publication, either on-line or in print, is copyrighted by the Informing Science Institute. Permission to make digital or paper copy of part or all of these works for personal or classroom use is granted without fee provided that the copies are not made or distributed for profit or commercial advantage AND that copies 1) bear this notice in full and 2) give the full citation on the first page. It is permissible to abstract these works so long as credit is given. To copy in all other cases or to republish or to post on a server or to redistribute to lists requires specific permission and payment of a fee. Contact Publisher@InformingScience.org to request redistribution permission.

\section{Introduction}

As Information Systems education enters its fifth decade, the outlook is mixed for Management Information Systems (MIS or Computer Information Systems-CIS) as a discipline and major in many business colleges. Throughout the history of MIS as an academic field, there have been marked shifts in under- 
graduate enrollment. Many, if not most, MIS Departments are still feeling the effects of the latest downturn in number of majors, a shift that began when the dot.com bubble burst in 2000/2001. Because enrollment remains a critical issue in MIS Departments, it is important to understand the factors by which students choose their major and, in particular, those students who choose similar, but not MIS, majors. In the competition for MIS majors, MIS faculty must be cognizant of some of its closest competitors: other business majors. Why do business students choose another business major instead of MIS? What factors are important in this choice? In order for MIS Departments to develop strategies to improve enrollment, they must first understand the importance of each influence in student choice of major. We should note that the term Management Information Systems (MIS), or Computer Information Systems (CIS), in terms of an academic discipline, differs depending on the university and the country in which it is located. These differences may include the amount of technology (or even engineering) involved in the courses as well as the college in which the department is housed (which in the U.S. is usually business, science, or (less likely) engineering). For the purposes of this paper, MIS (or CIS) refers to departments housed in the College of Business, probably the most prevalent in the U.S.

The trend in declining MIS (and indeed all technology majors) enrollments has been well documented (Downey, McGaughey, \& Roach, 2009; Foster, 2005; Frauenheim, 2004; Locher, 2007; Vegso, 2005). While this paper deals with MIS in the United States, and is focused as such, there are indications that this is also a global phenomenon (Zhang, 2007). The trend continues as we enter the second decade of the $21^{\text {st }}$ century, and it remains a concern for MIS professionals (Saunders \& Lockridge, 2011; Tabatabaei \& Tehrani, 2010). The current economic downturn has likely exacerbated the already alarming trend by causing the demand for all business majors to decline. This has not always been the case. In the late 1980s and into the 1990s, enrollment in MIS programs in the U.S. was booming (Goff, 2000) and MIS became one of the largest majors on many campuses. Computer science also experienced increasing growth in the enrollment within that same time frame (Vegso, 2005). As enrollments declined after 2001, however, MIS Departments faced increasingly significant problems, including faculty layoffs, restricted hiring, and budget reductions. Some universities even dismantled their MIS programs entirely (Aken \& Michalisin, 2007).

In order to reverse this trend, MIS faculty and administrators must be aware of and understand the factors that impel students to choose their particular major. In the competition for MIS majors, there are two primary competitors: other technology majors (notably computer science) and other business majors. One recent study examined the differences between MIS majors and computer science majors (Downey et al., 2009), concluding that MIS majors had a significantly greater interest in business and business organizations than did computer science majors. It is reasonable to conclude then that other business disciplines might appeal to potential MIS majors and that MIS departments compete for students not only with computer science, but also with other business disciplines. This study examines the differences between MIS majors and other business majors to understand why they choose, or do not choose, MIS.

There are many similarities between MIS majors and other business majors, given that they are all housed in the College of Business (COB; at least most MIS programs are located there). All business students take similar core and foundation business courses, including (typically) courses in accounting (Accounting 1/2), economics (Microeconomics/ Macroeconomics), and introductory courses in management, marketing, and finance. Most business majors require students to take an introduction to MIS course, and perhaps a computer skills course, both of which are typically service courses offered by MIS Departments. In general all business students earn the same degree (some type of BBA-Bachelor of Business Administration). It would seem apparent, then, that to attract more MIS majors, one must understand what prompts students to choose MIS instead of some other business major. 
Other studies have examined why students choose a major in business (Kim, Markham, \& Cangelosi, 2002; Mauldin, Crain, \& Mounce, 2000; Noël, Michaels, \& Levas, 2003; Pritchard, Potter, \& Saccucci, 2004; Strasser, Ozgur, \& Schroeder, 2002). These studies typically look at MIS only tangentially; only on occasion will a study directly compare MIS majors with the other business majors (e.g., Walstrom, Schamback, Jones, \& Crampton, 2008). These and similar studies examine discrete and isolated characteristics that may be important in a student's choice of major, without considering a framework that ties together these influences. This study directly compares MIS majors to all other business majors by examining the factors which lead students to select a particular major. It does so through the theoretical framework of TRA, the Theory of Reasoned Action (Ajzen \& Fishbein, 1980). TRA postulates that human behavior stems from one's intention to perform that behavior, which in turn is motivated by one's attitude toward the behavior as well as the beliefs of salient individuals toward the behavior (labeled Subjective Norm). In the case of this study, the pertinent behavior is the desire to work in the field of one's major choice (e.g., accounting majors desire to work as accountants). The primary intent of this study is to determine how MIS and non-MIS business majors differ in order to develop strategies to attract students to MIS who might otherwise opt for other business majors. These strategies would be most helpful prior to students picking their major, however they could have some benefit in prompting students to change their major. By understanding the influences which shape attitudes and the intention to work in a particular field, faculty will be better able to counsel and advise all students, hopefully increasing the number of MIS majors at the same time.

\section{TRA and Influences in Choice of Major: Literature Review}

\section{Theory of Reasoned Action}

The reasons and factors that influence a student to pick a particular major have been wellresearched. Prior to examining some of these influential factors, it is important to set the context for examining them. Most studies examine influences as disconnected items which in part propel a student to choose a particular major and by extension to work in that field (Malgwi, Howe \& Burnaby, 2005; Pritchard et al., 2004). By contrast, one study examined technology majors (MIS and computer science) and found that individual items of influence combined into six factors, including the influences of college, business, high school, nature of the work, interest, and external rewards or benefits such as salary (Downey et al., 2009). While this is helpful, it does not provide a theoretical framework by which to view these influences. Such a framework would provide a conceptual basis for examining student influences on choice of major, as well as the ability to compare and synthesize findings across similar studies, as recommended by researchers (Straub, 1989).

This study uses the Theory of Reasoned Action as its conceptual framework (Ajzen \& Fishbein, 1980). According to TRA, as applied in this study, a student's intention to work in a particular field (based on their major) is rooted in his or her attitude toward the major as well as Subjective Norm, the relevant beliefs of those individuals important to the student (such as family, friends, other students, professors, and high school teachers/advisors). A student thus chooses a major and intends to work in that field based on his/her attitude toward the major and the influence of others (Subjective Norm). A student's attitude toward the major is formed by his or her beliefs concerning a variety of important characteristics, such as interest, aptitude, salary, job availability and security, personal and social image, and difficulty/workload of a major.

Zhang (2007) used TRA as a framework for examining choice of major. He used students who had not yet chosen a major; the dependent variable was their intention to major in Information 
Systems (IS). IS, as a subset of Information Technology (IT), is what we call MIS in this study. For this current study, though the framework and constructs are similar to Zhang, the population, focus, and methodology are different. This study includes only students who have declared their major (a major in the College of Business) and examines the empirical similarities and differences between two groups: MIS majors and other business majors. By creating two models (MIS majors and other business majors), this study will empirically compare student attitudes and the influence of salient others. The focus is, therefore, not on undecided students who may or may not choose a MIS major, but on students who have chosen their major and the similarities and differences between MIS majors and all other business majors. Given this theoretical framework, we now examine items which influence students to select a major. In examining the literature, we separate the influences into two broad categories, internal and external influences, though there is some overlap (as with any taxonomy).

\section{External Influences}

External influences are those that are based on the major and projected career. These include such things as job characteristics (job security, job availability, and projected salary), prestige of employment in the field, and the degree of difficulty and workload of the major.

Job security and job availability refer to the difficulty or ease students will have in getting their first jobs after graduation and the likely availability of jobs throughout their careers. Some 30 years ago researchers found job security and availability important in students' choice of major (Hafer \& Schank, 1982). More recent studies produced similar findings: that the future outlook for jobs is important in picking one's major (Mauldin et al., 2000, Walstrom et al., 2008). Studies focusing on specific business majors like accounting, finance and MIS found job security and availability important (Niculescu, 2006; Sugahara, Boland, \& Cilloni, 2008). In light of the current global recession, job security and availability may be even more important to students today.

The importance of salary and earning potential in student choice of major has been highlighted in many studies (Berger, 1988; Farley \& Staniec, 2004; Felton, Buhr, \& Northey, 1994; Lowe \& Simons, 1997; Walstrom et al., 2008). All of these studies suggest that students tend to choose majors and work in career fields with good present and future potential for monetary rewards.

Social image or prestige or status can also affect a student's selection of a college major (Thomas $\&$ Allen, 2006). Studies report that majors and careers with a higher social image are preferred (Auyeung \& Sands, 1997; Sugahara et al., 2008). One study reported a stronger link between social image and choice of major for males than for females, suggesting a male's desire for status inclined him to select majors like business, which was perceived to have a higher social image (Leppel, Williams, \& Waldauer, 2001). A study designed to examine why business students tend not to major in MIS found prestige, along with career potential and interest, was an important influence on choice of a business major (Hogan \& Li, 2009).

Some students choose majors that they perceive to be easier than alternate choices. Some may feel unqualified or ill-prepared to select a difficult major, such as one in math, science, engineering, or even technology (Carter, 2006; Maple \& Stage, 1991). In a study of accounting majors, the amount of course work required to graduate was a significant influence in choice of major (Cohen \& Hanno, 1993). Some students tend to choose majors based in part on how difficult or easy the major is perceived to be (Calkins \& Welki, 2006; Lowe \& Simons, 1997).

The literature thus shows that numerous external influences impact student choice of major generally, and the choice of business majors in particular. Some of the influences tend to be tangible, like financial rewards and work required, while others are less tangible, like prestige or status. 


\section{Internal Influences}

Internal influences, though no doubt shaped in part by external forces, tend to reflect attitudes, beliefs, abilities, and personality. Internal influences include interest and aptitude in the field, one's personal image, and the influence of others.

Interest in the field has long been recognized as an important factor in choosing a major and working in that field following graduation (Adams, Pryor, \& Adams, 1994; Malgwi, Howe, \& Burnaby, 2005; Mauldin et al., 2000; Strasser et al., 2002). Several studies have found that interest in the field is the most influential factor in the choice of a college major (Downey et al., 2009; Kim et al., 2002; Zhang, 2007). It makes intuitive sense, backed by empirical evidence, that students typically choose major fields that they find interesting.

Aptitude toward one's major is another important influence. Students tend to choose majors they think they are good at or where a good "fit" exists. For example, students with high standardized scores in math and science tend to choose more quantitative or technical majors, while those with lower scores tend to choose majors such as one in liberal arts (Carter, 2006; Maple \& Stage, 1991). Perception of individual ability or aptitude can be just as important. Studies have found that those students who believed they had high technical abilities tended to choose math, science, or engineering majors (Farley \& Staniec, 2004; Lapan, Shaughnessy, \& Boggs, 1996). Research shows that business students, like others, also tend to pursue a fit with perceived ability (Kim et al., 2002; Lowe \& Simons, 1997).

Another potential influence in choosing a major is personal image. It is related to social image, which is a person's perception of the prestige or respect associated with a major. The difference is that for personal image, the object of the image is not the profession or major, but the individual. One's image of oneself with respect to one's major/career can have an influence in one's choice of that major or career. This may be especially significant for technology majors such as MIS; the perception that MIS majors are "geeks" or "nerds" may be demotivating to potential majors (Zhang, 2007).

Other people can be very influential in a student's choice of a college major. Labeled Subjective Norm in TRA, it holds that salient others influence one's intention to perform a behavior (Ajzen $\&$ Fishbein, 1980). There are many potential salient others for students selecting a major/career, which are reported in the literature. These include parents or family (Calkins \& Welki, 2006; Farley \& Staniec, 2004; Zhang, 2007), high school teachers or counselors (Calkins \& Welki, 2006; Mauldin et al., 2000), college instructors (Downey et al., 2009; Saemann \& Crooker, 1999; Strasser et al., 2002; Zhang, 2007), and friends or other students (Bartol, 1976; Calkins \& Welki, 2006; Mauldin et al., 2000). These influential others may provide information, opinions, verbal encouragement, and support regarding the selection of a college major. They may also serve as role models or vicarious examples of success or failure.

\section{Research Model}

The literature clearly suggests that there are many influences that shape a student's choice for a particular major and career. Many of these factors are experiential beliefs, that is, there is an expectation of a psychological reward that results from performing a particular behavior (Zhang, 2007). For example, interest in a behavior has been found to positively correlate with satisfaction and positive feelings toward the behavior (Jones \& Reynolds, 2006). Thus it would be expected that one's interest in a particular major should influence the person's attitudes toward the major, leading him or her to consider the behavior psychologically worthwhile (Zhang, 2007). Experiential beliefs shape attitudes toward the behavior (Ajzen \& Fishbein, 1980). 
Normative beliefs originate from salient others' opinions about whether the person should perform that behavior. As pointed out by Zhang (2007), in this population of undergraduate students of limited life experiences, normative beliefs may be even more influential than for older adults. In the TRA framework, normative beliefs are expected to influence the behavior of working in one's major field. The research model is provided in Figure 1.

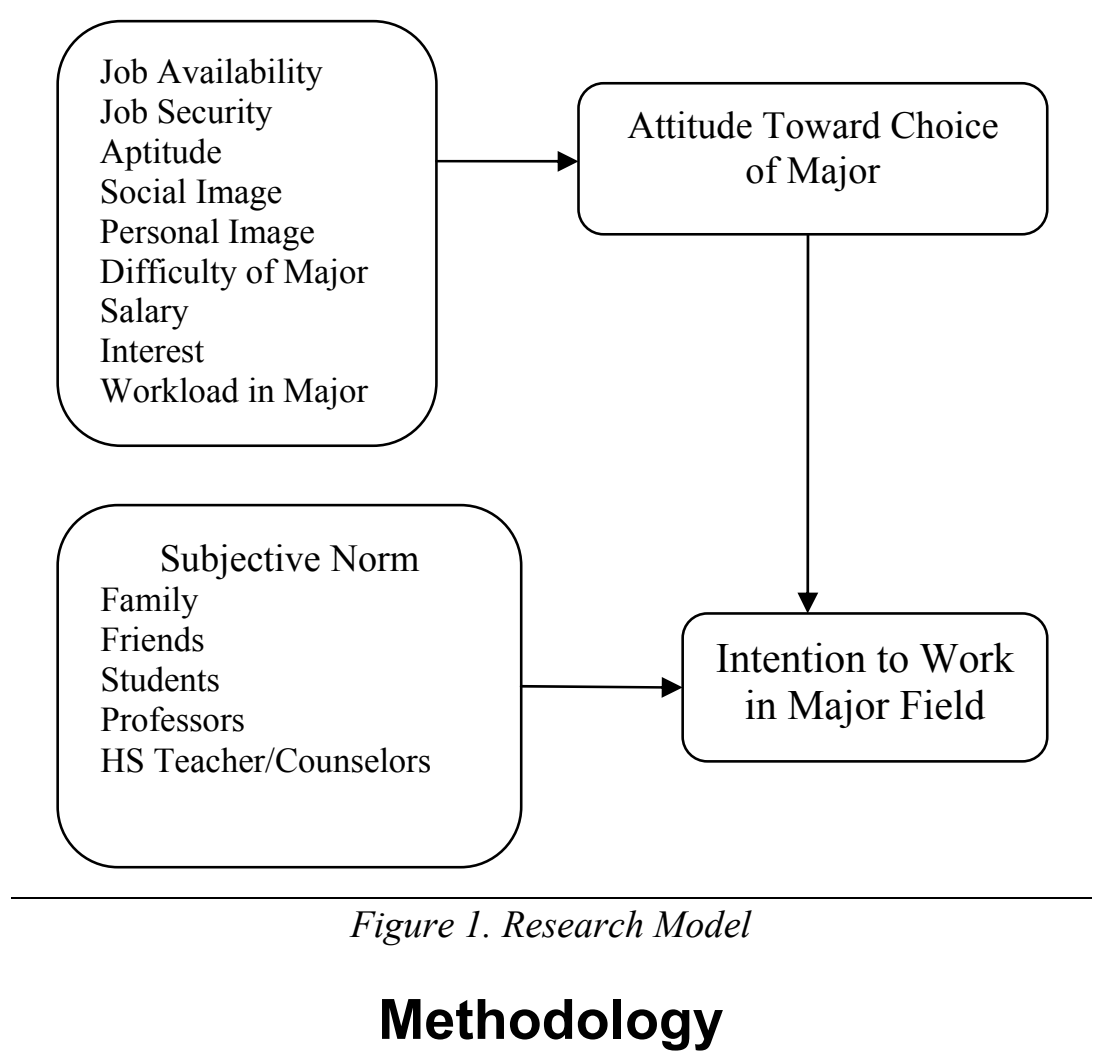

\section{Survey}

A survey was used to collect data. Most of the survey items were adopted from Zhang (2007), to provide both a comparison and replication. One primary difference between the two studies was respondents; Zhang examined students who had not yet declared their major, while this study used only students who had declared a major in the College of Business. All of the survey items in this survey were previously validated (Taylor \& Todd, 1995; Zhang, 2007). Each item was measured on a seven-point scale, with $1=$ "Completely Disagree" and $7=$ "Completely Agree".

All behavioral beliefs were measured with reflective indicators. The five normative beliefs (influence of family, friends, other students, professors, and high school teachers/advisors) were measured with formative indicators. Formative indicators need not covary, may be independent of each other, and "cause" the latent variable, rather than reflect or manifest the latent variable (Diamantopoulos \& Winklhofer, 2001). The impact of salient others (family, friends, etc.) on one's choice of major is discrete and therefore should be modeled as formative (Zhang, 2007). As such, each of these variables is expected to have a direct impact on a student's intention to seek employment in their major field. 


\section{Participants and Methodology}

Participants were college students majoring in business at a Southern university in the United States with an enrollment of approximately 12,000. At the time of the survey (2010), the College of Business included 1276 students who had selected one of the majors in the COB. These majors comprised eight different disciplines, including accounting, economics, finance, insurance/risk management, management, marketing, Management Information Systems (MIS), and general business. Almost all students in the COB were pursuing a BBA (Bachelor of Business Administration) degree, the only degree available for most undergraduate business majors. Of these students, we selected a total of 413 to survey. Table 1 summarizes sample demographic information.

Table 1. Demographic Information

\begin{tabular}{|l|l|c|c|c|}
\hline Major & $\mathbf{n}$ & \multicolumn{1}{c|}{ Age } & Male \% & Class \\
& & (mean/sd) & Female \% & Fr/So/Jr/Sr \\
\hline Accounting & 62 & $21.8(3.5)$ & $43 / 57$ & $2 / 11 / 28 / 21$ \\
\hline Economics & 16 & $20.7(1.1)$ & $69 / 31$ & $1 / 2 / 8 / 5$ \\
\hline Finance & 62 & $21.9(1.5)$ & $72 / 28$ & $0 / 2 / 15 / 45$ \\
\hline Insurance & 23 & $21.6(1.2)$ & $65 / 35$ & $0 / 2 / 4 / 17$ \\
\hline General Business & 62 & $22.3(3.7)$ & $56 / 44$ & $1 / 10 / 23 / 26$ \\
\hline MIS & 60 & $22.8(4.9)$ & $80 / 20$ & $0 / 7 / 15 / 38$ \\
\hline Marketing & 65 & $21.1(1.1)$ & $50 / 50$ & $0 / 12 / 28 / 25$ \\
\hline Management & 63 & $22.2(2.5)$ & $58 / 42$ & $0 / 8 / 29 / 26$ \\
\hline Total & $\mathbf{4 1 3}$ & $\mathbf{2 1 . 9 ( 3 . 0 )}$ & $\mathbf{6 0} / \mathbf{4 0}$ & $\mathbf{4 / 5 4 / 1 5 0 / 2 0 2}$ \\
\hline
\end{tabular}

In order to provide a cross-section of majors, we chose three courses to survey that were required of all business majors. These courses included Principles of Accounting 1 (taken mostly by sophomores), the management core class (Managing People and Work, taken mostly by juniors and seniors), and Managing Policy and Strategy (a capstone course taken by seniors). Because each course was a prerequisite of the next higher one, no student could take two simultaneously. None of these courses were part of the general education courses that any major could take for credit, which meant that only business majors were likely to be in these courses (after data collection, only twelve surveys were discarded because responses were not from a business major). After obtaining permission from both chairs and instructors, all sections (each of these courses was taught multiple times in the same semester) in each of these three courses were surveyed during class time.

\section{Results}

Data were analyzed using confirmatory factor analysis (CFA) and structural equation modeling (SEM) using SPSS and AMOS 17.0. The data were initially factor analyzed (using CFA) to examine construct dimensionality, reliability, and validity. This examination of the measurement model was conducted first with the entire sample, then with both sub-samples (MIS majors only and all majors but MIS). Finally the paths between latent variables were tested in the structural model.

Table 2 provides the initial examination of the constructs, including means and standard deviations. These data are divided into three groups, with the full sample $(n=413)$, and two subsamples, including MIS majors only $(\mathrm{n}=60)$ and all other majors (called NoMIS; $\mathrm{n}=353$ ). Respondents clearly intended to choose work in their major field, which had the highest mean for the full sample group (5.96 of 7.0 for the entire sample). Respondents also were quite happy 
about their choice of major (attitude toward choice, mean of 5.94) and were highly interested in their field (mean of 5.59). At the lower end of importance in choosing their major were influences of others, including high school teachers/advisors (mean of 2.27), friends (2.50), and other students (2.72).

Table 2. Means and standard deviations of variables

\begin{tabular}{|l|l|r|r|r|r|r|}
\hline & \multicolumn{3}{|c|}{ Means } & \multicolumn{3}{c|}{ SD } \\
\hline & All & NoMIS & MIS & All & NoMIS & MIS \\
\hline Intention to Work in Major & 5.96 & 5.94 & 6.06 & 1.07 & 1.05 & 1.19 \\
\hline Attitude to Choice & 5.94 & 5.92 & 6.08 & 1.14 & 1.17 & 0.91 \\
\hline Interest & 5.59 & 5.57 & 5.71 & 1.19 & 1.22 & 1.01 \\
\hline Aptitude & 5.51 & 5.48 & 5.72 & 1.04 & 1.06 & 0.90 \\
\hline Social Image & 5.47 & 5.49 & 5.36 & 1.02 & 1.01 & 1.04 \\
\hline Job Availability & 5.36 & 5.32 & 5.62 & 1.30 & 1.31 & 1.26 \\
\hline Job Security & 5.31 & 5.25 & 5.64 & 1.23 & 1.26 & 1.00 \\
\hline Salary & 5.24 & 5.20 & 5.48 & 1.08 & 1.08 & 1.05 \\
\hline Workload of Major & 4.19 & 4.18 & 4.23 & 1.46 & 1.44 & 1.56 \\
\hline Difficulty of Major & 3.48 & 3.46 & 3.60 & 1.43 & 1.40 & 1.63 \\
\hline Personal Image & 3.19 & 2.89 & 4.95 & 1.67 & 1.54 & 1.33 \\
\hline Professors & 2.97 & 2.84 & 3.77 & 1.90 & 1.82 & 2.13 \\
\hline Family & 2.94 & 2.90 & 3.15 & 1.78 & 1.79 & 1.75 \\
\hline Other Students & 2.72 & 2.65 & 3.12 & 1.68 & 1.65 & 1.81 \\
\hline Friends & 2.50 & 2.45 & 2.80 & 1.58 & 1.56 & 1.65 \\
\hline HS Teachers/Counselors & 2.27 & 2.25 & 2.42 & 1.64 & 1.62 & 1.75 \\
\hline
\end{tabular}

For the initial CFA, the entire sample was included $(n=413)$. The purpose of this step was to ensure that exogenous constructs were one dimensional and that items loaded significantly on their latent variable, with no high cross-loads. In this factor analysis, only reflective variables were included; formative variables had no items and were of course not latent variables. In addition, the endogenous (dependent) variables of intention to work in one's major and attitude toward choice were not included due to covariance, as recommended (Straub, Boudreau, \& Gefen, 2004). When the variables were factor analyzed simultaneously, almost all items loaded on their appropriate factors, with few high cross-loads, indicating some measure of convergent validity. Standardized loadings should be above .70 to demonstrate appropriate individual item reliability (Chin, 1998), which was the case for all but one indicator. DI2 ("My major requires too many hard courses") standardized loading was .61 for the Difficulty of Major construct. (See the Appendix for the factor analysis.) Next, the dimensionality of constructs was examined and was problematic for two constructs. Four items for two different latent variable constructs loaded on the same factor and were therefore not one-dimensional. The items included the two for job availability (JA1 and JA2) and the two items for job security (JS1 and JS2), with weights between .72 and .84 . This was not surprising, since a future graduate's perceived job security depends in large part on the availability of a job. Respondents considered these to be quite similar; job availability and security go hand in hand. Based on this conceptual link, these four items were combined into a single latent variable (job availability/security) for all subsequent analyses.

Reliability and validity were also examined for each of the two sub-samples and summarized in Tables 3 and 4 (for each sub-sample). Reliability was checked by calculating composite reliability (CR). For most latent variables in both sub-samples, CR was above .75. The only exception was the Intention to Choose variable for both sub-samples, where the CR was .65 (NoMIS) or .67 (MISOnly). Composite reliability should be above .70 (Yi \& Davis, 2003), though ones slightly below are also acceptable (Hair, Anderson, Tatham, \& Black, 1998). In order to demonstrate convergent and discriminant validity, all items should load significantly on their own latent con- 
struct and be higher than cross-loads onto other latent constructs. This was the case. Discriminant validity was also examined by calculating a latent construct's average variance extracted (AVE); its square root should be at least .70 and higher than correlations with other constructs (reflective constructs). Only one was below .70, Intention to Choose, which was .69 for the NoMIS subsample; all AVEs were higher than correlations. AVE is included diagonally in Tables 3 and 4 in bold face. Despite the two issues noted, the measurement model was deemed satisfactory.

Table 3. Correlations and Average Variance Extracted for variables of non-MIS sample. AVE is not applicable for formative variables. CR: composite reliability. AVE indicated in bold.

\begin{tabular}{|c|c|c|c|c|c|c|c|c|c|c|c|c|c|c|c|}
\hline \multicolumn{16}{|l|}{ Majors-No MIS } \\
\hline & \multirow[t]{2}{*}{ CR } & \multicolumn{14}{|c|}{ Correlations and AVE } \\
\hline & & 1 & 2 & 3 & 4 & 5 & 6 & 7 & 8 & 9 & 10 & 11 & 12 & 13 & 14 \\
\hline 1. Choosing & .65 & .69 & & & & & & & & & & & & & \\
\hline 2.Attitude & .94 & .63 & .92 & & & & & & & & & & & & \\
\hline 3. Interest & .92 & .51 & .77 & .84 & & & & & & & & & & & \\
\hline 4. Diffic. of major & .78 & .02 & -.08 & -.16 & .81 & & & & & & & & & & \\
\hline 5. Work in major & .76 & .12 & .11 & .01 & .63 & .77 & & & & & & & & & \\
\hline 6. Job Avail/Sec & .89 & .46 & .54 & .40 & .01 & .07 & .82 & & & & & & & & \\
\hline 7.Salary & .81 & .35 & .45 & .34 & .07 & .14 & .71 & .83 & & & & & & & \\
\hline 8. Pers. Image & .92 & .07 & .02 & -.02 & .34 & .33 & .19 & .21 & .92 & & & & & & \\
\hline 9. Soc. Image & .88 & .39 & .48 & .43 & -.02 & .09 & .60 & .68 & .14 & .84 & & & & & \\
\hline 10. Aptitude & .90 & .41 & .55 & .61 & -.35 & -.13 & .46 & .39 & .03 & .47 & .91 & & & & \\
\hline 11. Family & $\mathrm{n} / \mathrm{a}$ & .11 & .12 & .06 & .05 & .12 & .16 & .15 & .14 & .07 & .03 & na & & & \\
\hline 12. Friends & $\mathrm{n} / \mathrm{a}$ & .02 & .05 & .06 & .01 & .07 & .10 & .13 & .19 & .04 & .06 & .67 & na & & \\
\hline 13. Students & $\mathrm{n} / \mathrm{a}$ & .09 & .09 & .09 & .03 & .12 & .10 & .14 & .14 & .08 & .11 & .53 & .78 & na & \\
\hline 14. Professors & $\mathrm{n} / \mathrm{a}$ & .23 & .16 & .22 & .04 & .05 & .25 & .17 & .22 & .14 & .21 & .44 & .53 & \begin{tabular}{|l|l|}
.54 \\
\end{tabular} & na \\
\hline 15. HS & $\mathrm{n} / \mathrm{a}$ & .11 & .05 & .02 & .10 & .18 & .08 & .07 & .23 & .02 & -.01 & .43 & .53 & .46 & .53 \\
\hline
\end{tabular}

Table 4 Correlations and Average Variance Extracted for variables of MIS only sample. AVE is not applicable for formative variables. CR: composite reliability. AVE indicated in bold.

\begin{tabular}{|c|c|c|c|c|c|c|c|c|c|c|c|c|c|c|c|}
\hline \multicolumn{16}{|c|}{ Majors-MIS Only } \\
\hline & \multirow[t]{2}{*}{$\mathbf{C R}$} & \multicolumn{14}{|c|}{ Correlations and AVE } \\
\hline & & 1 & 2 & 3 & 4 & 5 & 6 & 7 & 8 & 9 & 10 & 11 & 12 & 13 & 14 \\
\hline 1. Choosing & .67 & .71 & & & & & & & & & & & & & \\
\hline 2.Attitude & .91 & .56 & .88 & & & & & & & & & & & & \\
\hline 3. Interest & .85 & .31 & .61 & .75 & & & & & & & & & & & \\
\hline 4. Diffic. of major & .84 & -.20 & -.29 & -.21 & .86 & & & & & & & & & & \\
\hline 5. Work in major & .75 & -.01 & -.17 & -.23 & .64 & .79 & & & & & & & & & \\
\hline 6. Job Avail/Sec & .88 & .47 & .55 & .32 & -.26 & -.07 & .81 & & & & & & & & \\
\hline 7.Salary & .83 & .14 & .36 & .18 & .03 & .10 & .65 & .85 & & & & & & & \\
\hline 8. Pers. Image & .84 & -.13 & .09 & .04 & -.11 & -.10 & .20 & .32 & .85 & & & & & & \\
\hline 9. Soc. Image & .88 & .20 & .37 & .19 & .18 & .23 & .53 & .76 & .19 & .84 & & & & & \\
\hline 10. Aptitude & .84 & .06 & .19 & .39 & -.34 & -.41 & .17 & .19 & .05 & .12 & .86 & & & & \\
\hline 11. Family & $\mathrm{n} / \mathrm{a}$ & .07 & -.02 & -.04 & .20 & .16 & -.01 & -.08 & .03 & -.03 & .02 & na & & & \\
\hline 12. Friends & $\mathrm{n} / \mathrm{a}$ & -.07 & -.10 & .05 & .21 & .13 & -.06 & -.04 & -.04 & -.03 & .18 & .79 & na & & \\
\hline 13. Students & $\mathrm{n} / \mathrm{a}$ & -.27 & -.19 & -.14 & .12 & .06 & -.22 & -.06 & .05 & -.08 & .11 & .50 & .76 & na & \\
\hline 14. Professors & $\mathrm{n} / \mathrm{a}$ & -.26 & -.12 & .06 & .22 & .26 & -.19 & .09 & .11 & .04 & .11 & .26 & .31 & .41 & $\mathbf{N a}$ \\
\hline 15. HS & $\mathrm{n} / \mathrm{a}$ & -.11 & -.06 & .18 & .24 & .22 & .06 & .25 & .03 & .25 & .36 & .53 & .66 & .52 & .41 \\
\hline
\end{tabular}

The structural model was examined next, using AMOS. AMOS is a covariance-based technique that uses maximum likelihood estimation. The two sub-samples were tested separately. Results are provided Figure 2; standardized path values above or to the left of the arrow are the results for the sub-sample NoMIS. Values below or to the right are the results for the sub sample MISOnly. 


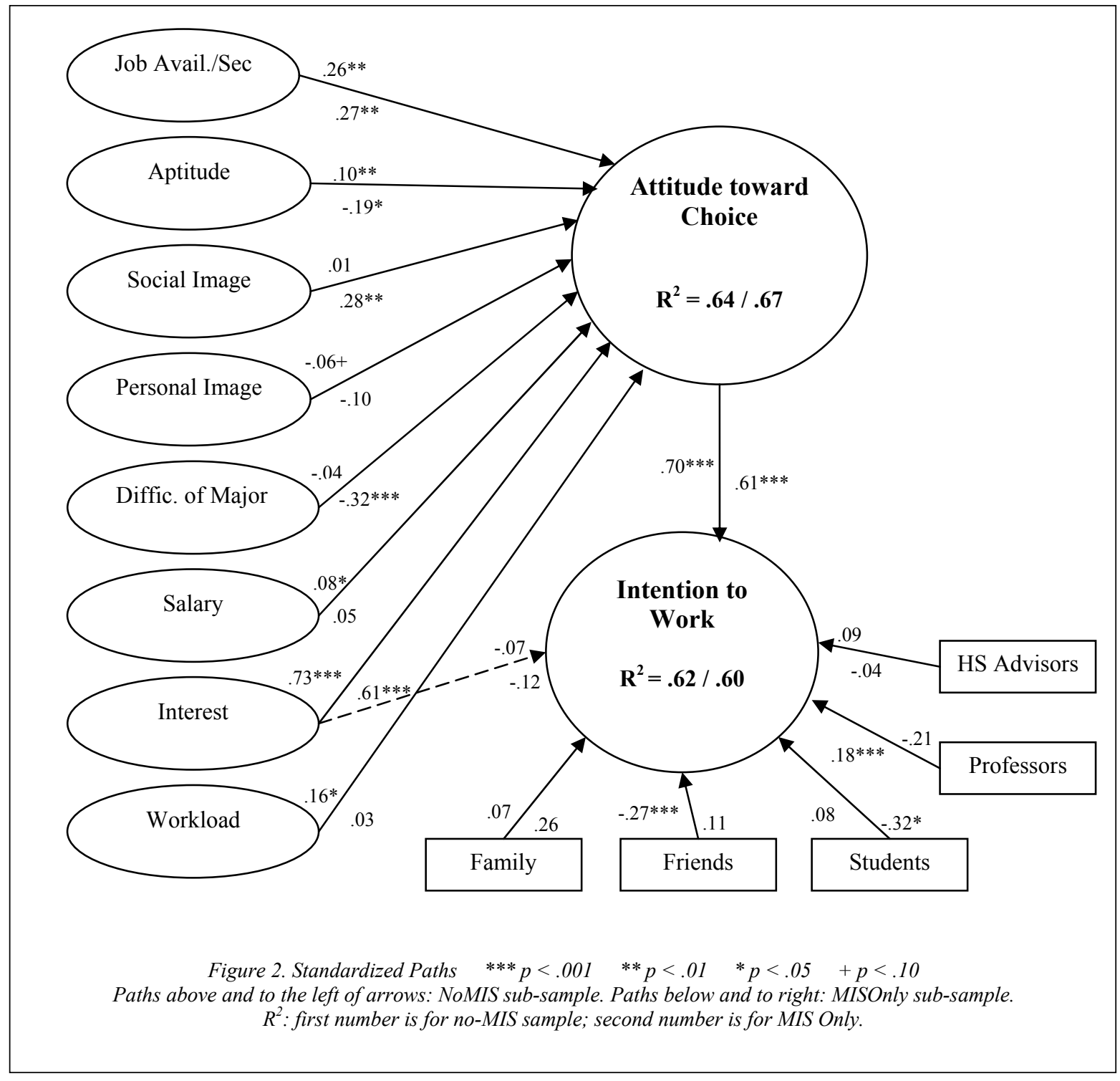

For both models, as predicted, one's attitude toward the choice of major was highly significant in his or her intention to work in the chosen field. For non-MIS majors, the loading was .70; for MIS majors it was .61. Of the eight latent variables predicting attitude toward choice of major, only three were significant for both sub-samples. Interest in the major was by far the most important factor influencing one's attitude toward one's choice of major, with paths of .73 (non-MIS) and .61 (MIS only). Job availability/security (.26 for non-MIS and .27 for MIS) and aptitude (.10 for non-MIS and -.19 for MIS) were the other two. The aptitude construct was surprising; its two items ("I am good at courses in my major" and "I have an aptitude for my major") produced opposite results for the two sub-samples. For non-MIS majors, one's perceived aptitude in one's major significantly enhanced attitude toward choosing the major, as one might expect. For MIS majors, however, one's aptitude had the opposite effect on attitude toward choice of major (Zhang, 2007, had a similar finding). Perhaps MIS majors were reacting against a supposed "geek" identity; this will be discussed in the next section. For the five social norm variables, only the influence of other students significantly predicted intention to work in major field for both sub-samples, and for one of these, non-MIS majors at .08, it was significant only at the $p<.10$ 
level. Interestingly, for MIS majors the path (-.32) was significant but negatively influenced intention; this was the same as aptitude.

Only one variable was not significant for either sub-sample, and that was the influence of high school teachers/counselors on intention to work in their major. For all the other variables, there were differences in significance between the non-MIS major sub-sample and the MIS subsample. For non-MIS majors, the following significantly predicted attitudes (or intention to work in the field for the social norm variables): influence of friends $(-.27 * * *)$, influence of professors $\left(.18^{* * *}\right)$, workload of major $\left(.16^{*}\right)$, salary $\left(.08^{*}\right)$, and personal image $(-.06+)$. None of these were significant for MIS majors. For the MIS majors, the following were significant (but not significant for non-MIS majors): difficulty of major $\left(-.32^{* * *}\right)$, social image $\left(.28^{* *}\right)$, and family $\left(.26^{*}\right)$.

\section{Discussion}

This study postulated that a student's attitude toward his or her choice of major influences the intention to choose career work in the major field and is in turn influenced by a variety of factors, including interest in the major field, job security and availability, aptitude, social and personal image, and difficulty of the major and its workload. A student's intention to work in his or her major field is not only influenced by attitude toward the major, but also by the influence of salient others in his/her life, collectively referred to as Subjective Norm, and includes family, friends, fellow students, professors, and high school teachers/advisors. The theoretical foundation for this model is the Theory of Reasoned Action, which suggests that human behavior is directly motivated by one's intention to perform that behavior (in this case working in one's major field) and that this intention is formed by one's attitude toward the behavior and Subjective Norm.

This study examined students in the College of Business who had already chosen a major and specifically examined the differences and similarities of MIS majors with a grouping of all other business majors. The impetus behind this study is simple; given the declining enrollments of many MIS/CIS departments, given that most MIS departments are housed in the business college, and given that MIS majors have an interest in business and not just an interest in technology, much of the competition for majors comes from other departments in the College or Business. It is important therefore for MIS departments to understand the attitudes and motivation of students who choose MIS, as well those of students who choose other business majors. This understanding should assist MIS faculty and administrators in efforts to recruit students to MIS and to retain MIS majors.

The results of the study confirm that the intention to work in a particular business field is directly and significantly influenced by one's attitude toward choice of major (standardized path values of $.70 / .61$ for no-MIS/MIS only). Including the five Subjective Norm variables, the amount of variance $\left(\mathrm{R}^{2}\right)$ explained by the model for intention to work in the field was .62/.60 (no-MIS/MIS only), very similar to the .65 found by Zhang (2007). The intention to work in one's major field in this study for both MIS and non-MIS majors was rated extremely high, 5.96 on a 7.0 scale. One's attitude toward choice of major was also rated extremely high, 5.94 of 7.0. The amount of variance explained for attitude toward choice of major was also high, .64/.67 (no-MIS/MIS only), again very similar to the .61 found by Zhang (2007). Students in the College of Business indicated their strong intention to work in their major after graduation and were quite happy with their choice of major. Despite some similarities, there were, however, many differences between MIS majors and non-MIS majors, some of which were rather striking. These results and their implications are summarized below.

1. Interest in the field remains the strongest predictor of attitudes in choice of major. Despite the recession that was ongoing during data collection, interest in one's major field was the 
strongest influence on one's attitude toward one's choice. The relationship was strong and positive, and consistent with other studies that found interest in one's major the most important factor in choosing a major (Downey et al., 2009; Kim et al., 2002; Malgwi et al, 2005; Zhang, 2007). It should be noted, however, that in this study interest influenced one's attitude toward choice of major, not the choice itself. Interest was by far the most important factor in determining one's attitude. As part of a post hoc analysis, the influence of interest directly on intent to work in the field (dotted line in Figure 2) was calculated but was not significant for either sub-sample (paths $.07 /-.12, \mathrm{p}=.38 / .52)$. The impact of interest is mediated by one's attitude toward choice only, which is the same result found by Zhang (2007).

For faculty, especially in the MIS field, the implication is that interest must be encouraged and facilitated. If more MIS majors are desired, more interest must be fostered. This can be done in a variety of ways. Greater attention should be placed on high school students. While most high school students have heard of computer science as a degree, as well as most of the other business majors (e.g., accounting, marketing, management, etc.), many are not aware of MIS (Downey et al., 2009). Anecdotally, one author recently spoke at a conference including some of the brightest young people (mostly high school students) from around the US. When he asked the students how many knew what MIS meant, 6 of approximately 50 raised their hands. This should be remedied. MIS faculty should increase their presence in the high schools, which could be done by making presentations to high schools in technology classes or involvement in clubs or conferences, such as FBLA (Future Business Leaders of America), Oracle Academy, and similar venues. Some universities hold IT summer camps for high school students, including the authors' own school, which can be successful in encouraging students to pursue MIS and IT careers. An effort should be made to inform high school teachers about MIS and what it offers students. While most studies of college students suggest that high school teachers have little influence on student choice of major, this should be regarded as an area of opportunity. Most universities with a College of Education have continuing education, and summer masters degree programs, for high school teachers. Efforts could be made to participate in those programs in some way to reach that target audience. They want to assist their students, but they need information.

Beyond high school, MIS faculty must promote interest in MIS in college students, and in particular those freshmen and sophomores who have not yet chosen a major. Some students know in high school what their major will be (most computer science majors, for example, decide in high school), while many others decide in college, including most MIS majors (Downey et al., 2009). Those undecided students are one group that MIS faculty should target to enhance their interest in IT. The most obvious way is inside the classroom, which means that the foundation courses business majors take within the college are important recruitment tools. As noted, most business programs require students to take a skills course of some kind (spreadsheets, databases perhaps) and most require some type of Introduction to MIS course. Assuming they are taught by MIS faculty, these courses provide an opportunity to promote interest in MIS at a time when students may not have picked a major, or at least when switching majors does not delay graduation. Studies show that the first course in a major is an important tool in gaining majors (Downey et al., 2009; Malgwi et al., 2005). Administrators should choose wisely who teaches these classes. The faculty member(s) who teach these courses are many students' first exposure to MIS; thus, they should make it interesting and enjoyable. Another way to enhance interest is with an MIS club open to non-majors. Enticements as simple as offering free food at meetings (and perhaps extra credit for students in MIS service course classes that include potential MIS majors) or interesting guest speakers addressing topics with broad appeal, such as social networking or E-commerce, can attract non-MIS majors to meetings. The key is that MIS faculty should actively promote interest in the MIS field to students prior to choosing a major as well as early in the educational process, when switching costs are minimal. Most business schools have a "general business" major, and students quite often end up in general business because, while they are attracted to busi- 
ness, they have not identified a particular career that appeals to them. Students in the general business major in particular should be targeted for recruitment to MIS.

2. Job availability and job security are strong influences on attitudes. Though interest in the major was the strongest predictor, job availability and security were both strong positive influences on attitudes. For all business majors, getting and keeping a job upon graduation is very important. In his analysis, Zhang (2007) found neither of these significant for students who had not yet chosen a major (the dependent variable in that study was intention to choose an IS major). That both were strongly significant in this study suggests a possible impact of the recession on student perceptions and/or perhaps that the students in this study differed because they had already chosen their major and were moving closer to graduation. This is clearly an important finding (though perhaps not surprising). Given the importance of job availability and security to nonMIS majors, this would be something that MIS faculty should stress to students who have not yet chosen their major, in those first required MIS classes. While some other business majors also have high placement rates upon graduation, it is probably fair to say that the outlook for MIS (and other IT careers) remains among the strongest. Projections in the Bureau of Labor Statistics Occupational Outlook Handbook for 2010-2011 as well as trade organizations like MyStaffingForce (Sussman, 2010) suggest a bright job outlook for such careers and students should be made aware of this. It is important not to exclude MIS majors. Though they have already selected the MIS major, it is important keep information in front of them, like salary and employment statistics, that supports their decision to major in MIS.

3. MIS majors embrace respect but not their skills. Perhaps the most surprising finding in this study was the influence of both aptitude and social image, particularly as compared to non-MIS majors. Social image was significant in its relationship with attitude for MIS majors $\left(.28^{* *}\right)$, but not for non-MIS majors (.01). It was measured with three items, all dealing with respect accorded professionals in the field ("look up to", "respect"). For MIS majors, this was the third most important contributor to attitudes toward choosing their major (after interest and difficulty of the major and slightly more important than job availability/security). For MIS majors, the respect or prestige afforded MIS professionals was very important in shaping their attitude toward the choice of major. For non-MIS majors, it was not significant. It is not clear whether non-MIS majors thought their major lacked respect or whether the respect it possessed was just not very important in shaping their attitude. One possibility is that recent events like the troubles of the financial industry and the bashing of BP's management/marketing decisions related to the Gulf of Mexico oil spill may have soured the perceived respect of those in other business majors. Another possibility is that non-MIS business majors may "respect" business leaders but do not see themselves in such high positions, at least not in the immediate future. As a result, many nonMIS business majors may not identify with those who are seen as having prestige and respect in the field. By contrast, the individuals who have been successful in technology include a young Bill Gates, a young Steve Jobs, and, more recently, a young Mark Zuckerberg. MIS majors may see themselves as relatively similar to these individuals; they may self-identify with a Mark Zuckerberg and Facebook, as depicted in the recent movie, The Social Network.

Whatever the reason, clearly respect is important for MIS majors. This is important to understand and use, especially in recruiting students who have not selected a major. Stressing the respect and prestige of the MIS profession (again particularly in early courses) could attract students to MIS, and emphasizing the accomplishments of people like Bill Gates and Mark Zuckerberg would seem appropriate. Though it may or may not attract students with other interests, it should appeal to students who are interested in technology.

Aptitude was significant for both non-MIS majors (.10**) as well as MIS majors (-.19*). The difference was in the valence and this finding is perplexing. The two items for aptitude ("I am good at courses in my major" and "I have an aptitude for my major") measure one's perceived 
talent and fit with their major. For both non-MIS and MIS majors, the means were high (5.48/5.72 respectfully), indicating that all majors believed in their own skills with respect to their major. Intuitively, if a person believes there is a fit between their talent and a particular major, it should enhance their attitude toward choosing that major. One tends to choose what one is good at (Downey et al., 2009; Pritchard et al., 2004). This was true for non-MIS majors, where their high perceived aptitude significantly and positively influenced their attitude toward choice of major. For MIS majors their high perceived aptitude also influenced attitude toward choice of major, but negatively.

One potential reason for aptitude negatively influencing attitude is that MIS majors may not perceive a link between their performance in school (which is dependent on their aptitude) and their potential reward of a good job upon graduation. Expectancy theory suggests that an individual's motivation and attitude depend on a perceived link between effort and performance (expectancy), a perceived link between performance level and reward level (instrumentality), and satisfaction of the reward (Porter \& Lawler, 1968; Vroom, 1964). Expectancy theory is a multiplicative model, where a low result on any of the three components produces low motivation, no matter how high either one or both of the other dimensions. For MIS majors, their high aptitude suggests expectancy, but they may not perceive high instrumentality, because their performance may not lead to a rewarding job. This may be particularly relevant given the current recession and the belief that many MIS jobs are being outsourced.

Equity theory offers additional insight. Equity theory suggests that individuals compare themselves to specific referent others and compare their own rewards (relative to contribution and what the individual brings to the table) to the rewards/contributions of referent others (Adams, 1963). Based on this comparison, individuals develop fairness perceptions and are likely to be dissatisfied in the face of inequity, if it is perceived to exist. Though our data do not allow us to verify it, MIS majors may perceive themselves as having to work harder than other business majors to earn a degree, yet not have a reward to go along with it (a secure, good-paying jobconsidering the poor economic conditions); thus, they perceive inequity and this negatively influences their attitude toward their choice of major. Ongoing reinforcement of MIS majors' choice of major with salary and job statistics, especially statistics on recent graduates, seems desirable. That information should also be used in recruitment.

4. Other people influence MIS majors differently. MIS and non-MIS majors differed for four out of the five normative variables. Family, friends, other students, and professors were all significantly different. The only normative variable where there was no difference was high school influences, which was not significant for either MIS or non-MIS majors. For non-MIS majors, three of the four normative variables positively influenced one's intention to work in their major field. That is, most salient people positively influenced this intention. One of the three, family, was positive but not quite significant ( $\mathrm{path}=.07 ; \mathrm{p}=.102$ ); the other two were significant at least at $\mathrm{p}<.10$ (professors $.18^{* * *}$ and students $.08+$ ). The one that had a negative influence was friends $(-.27 * * *)$. So other students and professors positively influenced intention to work in the field, and family was positive but not significant. Given the disparity between friends and students, it seems that non-MIS majors' friends and other students were not the same reference group (the same was true for MIS majors). In the survey, the "friends" item was first, followed immediately by "other students", probably leading respondents to consider them differently (which was the intent in the survey). For non-MIS majors, their intention to work in the field appears to be in spite of their friends' beliefs! One reason for such findings could be the generally negative image portrayed of business people today in the media. Part of this is self-inflicted, given the Enron scandal (and others) and the current recession blamed at least in part on greedy bankers. Many business students likely have friends who are non-business majors who may demean them for being business majors. MIS majors, on the other hand, probably have more 
friends who also find technology interesting, and so support their choice of major, leading to a positive relationship between friends and intention to work in the major. The influence of other students was positively significant for non-MIS majors (.08+) and negatively significant for MIS majors $(-.32 *)$. Like friends, the influences are in opposite directions. For both MIS and nonMIS majors, "other students" (from survey) are likely other business majors. These students apparently support majors other than MIS, perhaps believing technology majors "geeks" or "nerds". Such a belief would simultaneously provide support for the positive influence for non-MIS majors and the negative influence of MIS majors.

For MIS majors, two of the four normative variables had a positive influence and two had a negative influence on intention to work in the field: family $\left(.26^{*}\right)$, friends $(.11 \mathrm{~ns})$, other students ($.32 *)$ and professors $(-.21 \mathrm{~ns})$. Though two were non-significant, their valence is noteworthy. Friends and family support their intention to work in MIS; other students and professors (next section) negatively influenced them.

This rather remarkable finding of the difference between MIS and non-MIS is worth noting. As mentioned, for MIS majors, friends may very well be others interested in technology, and therefore supportive (Downey et al., 2009), which is why the relationship is positive (though not significant). For non-MIS majors, the influence of friends was strongly negative. If we wish to attract MIS majors, the salient others that influence them are family and friends. MIS administrators and faculty should develop strategies that gain the support of those influential others. Some tactics of such strategies have already been suggested, including working at the high school level, where parents and other family members are more accessible. Hold IT summer camps, where parents drop off their children to spend time with like-minded young people (and include a way for parents to participate in some of it). Promote an MIS or IT club in the MIS Department, offering extra credit in classes for showing up to encourage participation of non-MIS majors.

5. MIS professors must step up. Another interesting finding was that for non-MIS majors faculty positively and significantly reinforced attitudes while for MIS majors the influence was negative. Despite its non-significance for the MIS major sub-sample (path of $-.21, \mathrm{CR}=-1.635$, $\mathrm{p}=.102$ ), it was clearly a negative reinforcement (and almost significant at the $\mathrm{p}<.10$ level).

Had the finding been non-significant but positive, it would have been less alarming. This may be a localized finding, but perhaps not. It may simply be because many MIS classes are challenging and structured, so students are not playing with the technology, but instead they are working with it and work is not necessarily fun. Some MIS classes demand much student time and effort and students may not particularly like it. Regardless of the reason for this finding, it seems clear that MIS faculty should attempt to more positively influence the attitudes toward choice of major, by fostering a more positive impression of MIS. This is an area of opportunity.

6. Focus on other characteristics important to non-MIS majors. In addition to the characteristics already discussed, two others stand out in the study as important in shaping attitudes toward one's major that were significant only for non-MIS majors. These are salary and the workload of the major. In order to attract students who may major in something other than MIS (or who have already selected a non-MIS major), these are two areas that are worth pursuing. They are not significant for MIS majors, so once MIS has been selected, their value as motivators is questionable; however they are clearly important for non-majors. Salary was rated highly for all business majors (5.25 of 7.0), and was an important contributor to positive attitudes for non-MIS majors. Recent data suggest that MIS salaries are quite competitive in comparison to other business majors (Occupational Outlook Handbook, 2010-2011), and this fact should be stressed. The other characteristic was workload of the major. Though it was not as highly ranked as salary, it was still above the average (4.19 of 7.0). That the workload construct was significant for non-MIS majors means that the amount of work required to graduate is an important consideration. This suggests that the workload of their major is manageable, given that it positively influenced attitudes. To 
promote MIS, these students want to hear that they can manage MIS courses. This is a more difficult argument to make, because in general the MIS curriculum is probably tougher than some (or most) other business majors (possibly excepting accounting). Faculty should stress, however, that while challenging, it is doable. They can stress the positive aspects of the degree that many students may like, such as opportunities to manage and work with technology. Though beyond the scope of this paper, and perhaps controversial, another option is adjusting the curriculum. Some MIS departments require one or more programming courses, but perhaps they are not necessary for all MIS majors. In fact, the latest IS Curriculum standards barely mention programming courses (Topi et al., 2010). Working with employers who hire a department's graduates, understanding current talent requirements in the MIS job market, and staying abreast of the many changes in the MIS/IT field should allow MIS departments to hone their curriculum and perhaps make it accessible and desirable to more students.

7. Distal influences were less important to business majors. Not surprisingly, the more distal the influence, the less important the factor was in shaping attitudes toward a major. The influences from high school, for example, were not significant to any majors, non-MIS or MIS. The lowest means for any measured variable included the influence of high school teachers/advisors (2.27 of 7.0), friends (2.50), and other students (2.72). While some may argue the distal part, some friends and perhaps other students may be more distal than the other influences which shape attitudes and the intention to work in one's major field. This may be an area that provides an opportunity for MIS faculty, particularly the interaction with high school students, as previously mentioned. MIS programs and professionals need to educate the public, public school teachers and parents in particular, so that they recognize the MIS degree as an alternate route to rewarding careers in Information Technology.

\section{Limitations and Conclusion}

There are several limitations to a study such as this one. All the participants in this study came from one university, in the United States, which naturally limits generalizability. To enhance generalizability, other universities should be assessed, from other parts of the U.S. as well as globally. There are also other factors that could have been included but were not. For example, socioeconomic factors may be important in one's choice of major (Leppel et al., 2001), personality (Noël et al., 2003), and even other attitudes such as self-efficacy or anxiety. Finally, this study grouped together all non-MIS majors in order to compare them to MIS majors. There are clearly differences between non-MIS majors; accounting and marketing majors no doubt differ in many significant ways. The intent of this study was to examine all the non-MIS majors as a whole, in order to define general areas of difference and to develop some broad strategies to win more majors. A more comprehensive study should examine differences between MIS and other individual business majors that are not MIS. This would provide an additional clarification of the differences between majors and allow more focused strategies to gain majors (both those who may switch as well as those undecided).

This study examined the differences between MIS majors and non-MIS majors at a U.S. university with respect to factors important in their attitudes toward their choice of major and their intention to work in the major field. The study used the Theory of Reasoned Action (TRA) as a framework. The study found that attitudes toward one's choice of major significantly influenced one's intention to work in the major field. For all majors, interest was the most important factor in one's attitude toward their choice of major. But the study also found significant differences between MIS majors and non-MIS majors, in terms of aptitude, social image, personal image, difficulty and workload of major, salary, and most social normative items, including family, friends, other students, and professors. Faculty and administrators should use these differences in a variety of ways to attract undecided students to major in MIS as well as students who may wish 
to switch majors. In particular, to increase MIS majors, departments may want to concentrate on emphasizing respect in the major, the differences noted on normative beliefs (salient personal influences), refocus MIS professors', and reemphasize salary and workload in the major. Understanding the influences which shape a student's decision to major in a particular business field is important for both student and academic department. For MIS Departments who want to increase enrollment, this is critical, especially given that other business departments provide the closest competitors in number of majors. Influencing students who may be thinking of majoring in another field (and not MIS) requires a firm understanding of these influences.

\section{References}

Adams, J. S. (1963). Toward an understanding of inequity. Journal of Abnormal and Social Psychology, $67,422-436$.

Adams, S. H., Pryor, L. J., \& Adams, S. L. (1994). Attraction and retention of high-aptitude students in accounting: an exploratory longitudinal study. Issues in Accounting Education, 9(1), 45-58.

Ajzen, I., \& Fishbein, M. (1980). Understanding attitudes and predicting social behavior. Englewood Cliffs, NJ: Prentice-Hall.

Aken, A., \& Michalisin, M. D. (2007). The impact of the skills gap on the recruitment of MIS graduates, SIGMIS-CRP 2007, April 19-21, 2007, St. Louis, Missouri, USA, 105-111.

Auyeung, P., \& Sands, J. (1997). Factors influencing accounting students' career choice: A cross cultural validation study. Accounting Education, 6(1), 13-23.

Bartol, K. M. (1976). Expectancy theory as a predictor of female occupational choice and attitude toward business. Academy of Management Journal, 19, 669-675.

Berger, M. C. (1988). Predicted future earnings and choice of college major. Industrial \& Labor Relations Review, 41(3), 418-429.

Carter, L. (2006). Why students with an apparent aptitude for computer science don't choose to major in computer science. SIGCSE '06', March 1-5, 2006, Houston, Texas, USA, 27-31.

Calkins, L. N., \& Welki, A. (2006). Factors that influence choice of major: Why some students never consider economics. International Journal of Social Economics, 33(8), 547-564.

Chin, W. (1998). The partial least squares approach for structural equation modeling. In G. Marcoulides (Ed.), Modern methods for business research (pp. 295-358). Mahwah: Lawrence Erlbaum Associates.

Cohen, J., \& Hanno, D. (1993). An analysis of underlying constructs affecting the choice of accounting as a major. Issues in Accounting Education, 8(2), 219-238.

Diamantopoulos, A., \& Winklhofer, H. (2001). Index construction with formative indicators: An alternative to scale development. Journal of Marketing Research, 38(2), 269-277.

Downey, J., McGaughey, R., \& Roach, D. (2009). MIS versus computer science: An empirical study of the influences on the student's choice of major. Journal of Information Systems Education, 20(3), 357368.

Farley, J., \& Staniec, O. (2004). The effects of race, sex, and expected returns on the choice of college major. Eastern Economic Journal, 30(4), 549-563.

Felton, S., Buhr, N., \& Northey, M. (1994). Factors influencing the business student's choice of a career in chartered accountancy. Issues in Accounting Education, 9(1), 131-141.

Foster, A. L. (2005, May 27). Student interest in computer science plummets: Technology companies struggle to fill vacant positions. The Chronicle of Higher Education, 51(38), A31-A32.

Frauenheim, E. (2004, August 11). Students saying no to computer science. ZDNet News. Retrieved from http://news.zdnet.com/2100-3513_22-5306096.html 
Goff, L. (2000). MIS: Big major on campus. Computerworld, 34(28), 44-45.

Hafner, J., \& Schank, G. (1982). The business major: Making the choice. Journal of College Placement, $42(4), 47-49$.

Hair, J., Anderson, R., Tatham, R., \& Black, W. (1998). Multivariate data analysis. Upper Saddle River, NJ: Prentice Hall.

Hogan, P., \& Li, L. (2009). The perceptions of business students regarding management information systems (MIS) programs. Journal of Technology Research, 2, 1-8.

Jones, M., \& Reynolds, K. (2006). The role of retailer interest on shopping behavior. Journal of Retailing, 82(2), 115-126.

Kim, D., Markham, F., \& Cangelosi, J. (2002). Why students pursue the business degree: A comparison of business majors across universities. Journal of Education for Business, 78(1), 28-32.

Lapan, R. T., Shaughnessy, P., \& Boggs, K. (1996). Efficacy expectations and vocational interests as mediators between sex and choice of math/science college majors: A longitudinal study. Journal of Vocational Behavior, 49, 277-291.

Leppel, K., Williams, M., \& Waldauer, C. (2001). The impact of parental occupation and socioeconomic status on choice of college major, Journal of Family and Economic Issues, 22(4), 373-394.

Locher, M. (2007). IT Education: Where have all the young geeks gone. CIO, 20(15), 49-53.

Lowe, D., \& Simons, K. (1997). Factors influencing choice of business majors-some additional evidence: A research note. Accounting Education, 6(1), 39-45.

Malgwi, C., Howe, M., \& Burnaby, P. (2005). Influences on students' choice of college major. Journal of Education for Business, 80(5), 275-282.

Maple, S. A., \& Stage, F. K. (1991). Influences on the choice of math/science major by gender and ethnicity. American Educational Research Journal, 28(1), 37-60.

Mauldin, S., Crain, J. L., \& Mounce, P. H. (2000). The accounting principles instructor's influence on students' decision to major in accounting. Journal of Education for Business, 75(3), 142-148.

Niculescu, M. (2006). Strategic positing in Romanian higher education. Journal of Organizational Change Management, 19(6), 725-737.

Noël, N., Michaels, C., \& Levas, M. (2003). The relationship of personality traits and self-monitoring behavior to choice of business major. Journal of Education for Business, 78(3), 153-157.

Occupational Outlook Handbook. (2010-2011). US Bureau of Labor Statistics. Retrieved from http://www.bls.gov/oco/

Porter, L. W., \& Lawler, E. E. 1968. Managerial attitudes and performance. Homewood, IL: Richard D. Irwin, Inc.

Pritchard, R., Potter, G., \& Saccucci, M. (2004). The selection of a business major: Elements influencing student choice and implications for outcomes assessment. Journal of Education for Business, 79(3), 152-156.

Saemann, G. P., \& Crooker, K. J. (1999). Student perception of the profession and its effect on decisions to major in accounting. Journal of Accounting Education, 17(1), 1-22.

Saunders, G., \& Lockridge, T. (2011, January). Declining MIS enrollment: The death of the MIS degree? Contemporary Issues in Education Research (CIER), North America, 4, January 2011. Retrieved from http://journals.cluteonline.com/index.php/CIER/article/view/978

Strasser, S. E., Ozgur, C., \& Schroeder, D. L. (2002). Selecting a business major: An analysis of criteria and choice using the analytical hierarchy process. Mid-America Journal of Business, 17(2), 47-56.

Straub, D. W. (1989). Validating instruments in MIS research. MIS Quarterly, 10(2), 147-169. 
Straub, D., Boudreau M., \& Gefen, D. (2004). Validation guidelines for IS positivist research. Communications of the Association for Information Systems, 13, 380-427.

Sugahara, S., Boland, G., \& Cilloni, A. (2008). Factors influencing students' choice of an accounting major in Australia. Accounting Education, 17(1), 37-54.

Sussman, J. (2010, October 14). IT job outlook positive - Budgets set to increase in 2011 [Web log comment]. MyStaffingForce.com. Retrieved from http://www.mystaffingforce.com/profiles/blogs/it-joboutlook-positive

Tabatabaei, M., \& Tehrani, M. (2010). Factors impacting enrollment in information systems programs. Issues in Information Systems, 17(1), 319-321.

Taylor, S., \& Todd, P. (1995). Understanding information technology usage: A test of competing models. Information Systems Research, 6(2), 144-176.

Thomas, T., \& Allen, A. (2006.) Gender differences in students' perceptions of information technology as a career. Journal of Information Technology Education, 5(1), 165-178. Retrieved from http://www.jite.org/documents/Vol5/v5p165-178Thomas157.pdf

Topi, H., Valacich, J., Wright, R., Kaiser, K., Nunamaker, J., Sipior, J., \& Vreede, G. (2010). IS 2010 Curriculum guidelines for undergraduate degree programs in information systems. Published jointly by Association of Computing Machinery (ACM) and Association of Information Systems (AIS).

Vegso, J. (2005). Interest in CS as a major drops among incoming freshmen. Computing Research News, 17(3). Retrieved from http://www.cra.org/CRN/articles/may05/vegso

Vroom, V. H. (1964). Work and motivation. New York: McGraw Hill.

Walstrom, K. A., Schambach, T. P., Jones, K. T., \& Crampton, W. J. (2008). Why are students not majoring in information systems? Journal of Information Systems Education, 19(1), 43-54.

Yi, M. Y., \& Davis, F.,D. (2003). Developing and validating an observational learning model of computer software training and skill acquisition. Information Systems Research, 14(2), 146-169.

Zhang, W. (2007). Why IS: Understanding undergraduate students' intentions to choose an information systems major. Journal of Information Systems Education, 18(4), 447-458. 


\section{Appendix}

\begin{tabular}{|l|l|l|l|l|l|l|l|l|}
\hline \multicolumn{1}{|c|}{ Appendix. Factor Analysis of Independent Variables } \\
\hline & $\mathbf{1}$ & $\mathbf{2}$ & $\mathbf{3}$ & $\mathbf{4}$ & $\mathbf{5}$ & $\mathbf{6}$ & $\mathbf{7}$ & $\mathbf{8}$ \\
\hline 1. JA1 & $\mathbf{. 8 4}$ & .11 & .17 & .10 & .05 & .12 & -.03 & -.12 \\
\hline 2. JA2 & $\mathbf{. 8 3}$ & .08 & .19 & -.01 & .10 & .19 & .12 & -.06 \\
\hline 3. JS1 &. $\mathbf{7 7}$ & .21 & .27 & -.08 & .05 & .04 & .31 & .12 \\
\hline 4. JS2 &. $\mathbf{7 2}$ & .25 & .25 & .01 & .11 & .05 & .33 & .12 \\
\hline 5. SA1 & .46 & .16 & .39 & -.01 & .02 & .09 & $\mathbf{. 6 1}$ & .07 \\
\hline 6. SA2 & .39 & .05 & .33 & .11 & .18 & .13 & $\mathbf{. 7 0}$ & -.06 \\
\hline 7. SI1 & .20 & .12 &. $\mathbf{7 5}$ & .16 & .02 & .04 & .36 & -.05 \\
\hline 8. SI2 & .25 & .16 & $\mathbf{. 8 7}$ & .01 & .03 & .12 & .09 & .02 \\
\hline 9. SI3 & .36 & .22 & $\mathbf{. 7 9}$ & -.01 & .02 & .21 & .09 & .05 \\
\hline 10. PI1 & .12 & .00 & .05 & .11 & $\mathbf{. 9 3}$ & .03 & .05 & .11 \\
\hline 11. PI2 & .08 & -.02 & .01 & .13 & $\mathbf{. 9 5}$ & .02 & .07 & .03 \\
\hline 12. Apt1 & .19 & .31 & .12 & -.13 & .01 & $\mathbf{. 8 4}$ & .10 & -.15 \\
\hline 13. Apt2 & .18 & .36 & .22 & -.11 & .06 & $\mathbf{. 8 1}$ & .07 & -.08 \\
\hline 14. DI1 & .01 & -.05 & .03 & .40 & .11 & -.16 & -.03 & $\mathbf{. 8 2}$ \\
\hline 15. DI2 & -.06 & -.12 & -.03 & .52 & .18 & -.14 & .10 &. $\mathbf{. 6 1}$ \\
\hline 16. W1 & .08 & .08 & .08 & $\mathbf{. 8 1}$ & -.02 & -.03 & -.04 & .22 \\
\hline 17. W2 & -.01 & -.04 & .04 & $\mathbf{. 8 5}$ & .21 & -.09 & .08 & .02 \\
\hline 18. Int1 & .18 & $\mathbf{. 8 6}$ & .17 & .02 & -.03 & .20 & .05 & -.09 \\
\hline 19. Int2 & .15 & $\mathbf{. 8 9}$ & .17 & .02 & -.01 & .16 & .10 & .01 \\
\hline 20. Int3 & .13 &. .86 & .09 & -.06 & .01 & .18 & .01 & -.01 \\
\hline
\end{tabular}

JA: job availability; JS: job security; SA: salary; SI; social image; PI: personal image;

Apt: aptitude toward major; DI: difficulty of major; WI: workload of major;

Int: intention of working in major field.

\section{Biographies}

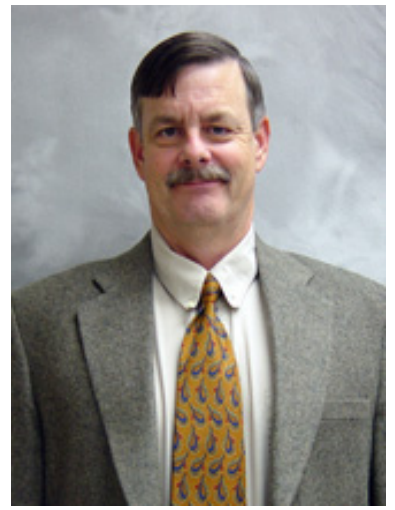

James P. Downey (Ph.D. Auburn University) is an associate professor in the MIS Department in the College of Business at the University of Central Arkansas. He received his Ph.D. in Management Information Systems. He spent 25 years as a Naval officer, including a tour at the U.S. Naval Academy, before leaving the Navy in November 2004. His current research interests include project management, database management, neural networks, and individual differences in behavior in human-computer interactions and end-user computing. He has published articles in Journal of Organizational and End User Computing, International Journal of Training \& Development, Journal of Information Systems Education, Interacting with Computers, Journal of Information Technology Education, Journal of Quantitative Analysis in Sports, among others. 
Ronald E. McGaughey (Ph.D., Auburn University) is a Professor of Management Information

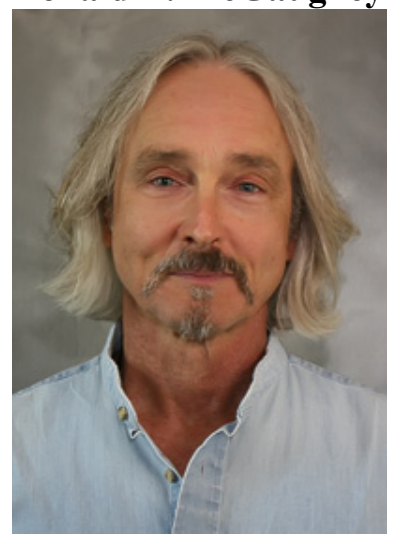
Systems at the University of Central Arkansas. His research appears in the Journal of Systems Management, Information and Management, International Journal of Production Economics, International Journal of Computer Integrated Manufacturing, Journal of Information Technology Management, Production Control, Benchmarking: An International Journal, Journal of Electronic Commerce in Organizations, the European Journal of Operational Research and more. He is the Internet Editor for Benchmarking: an International Journal and serves on the editorial board of numerous journals. He has practical management experience in the textile, construction and logging industries. His current research interests include advanced manufacturing technology, ECommerce, M-Commerce, and IT Careers.

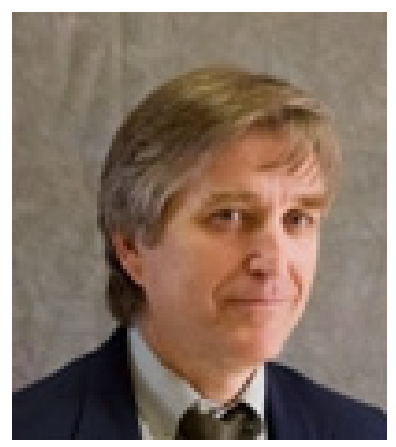

Dave Roach (Ph.D., University of Arkansas) is a Professor of Management at the Arkansas Tech University. His research appears in the Journal of Applied Psychology, Human Relations, Journal of the Academy of Marketing Science, International Journal of Computer Integrated Manufacturing, Journal of Information Technology Management, International Journal of Business Information Systems, Journal of Information Systems Education and more. His current research interests interpersonal perceptual and rating accuracy, business ethics, critical thinking, and IT education. 